\title{
APLIKASI GAME EDUKASI BERBASIS ANDROID SEBAGAI MEDIA PEMBELAJARAN ANAK BALITA
}

\author{
${ }^{1}$ Abi Febriyanto ${ }^{2}$ Untoro Apsiswanto ${ }^{3}$ Usep Saprudin \\ ${ }^{1}$ Abi Febriyanto. STMIK Dharma Wacana, Abyfebriyan85@gmail.com \\ ${ }^{2}$ Untoro Apsiswanto, STMIK Dharma Wacana, untorolampung@gmail.com \\ ${ }^{3}$ Usep Saprudin, STMIK Dharma Wacana, usepkreatif@gmail.com \\ Jalan Kenanga No. 3 Mulyojati Kota Metro
}

\begin{abstract}
Abstrack
Usia balita merupakan masa menerapkan dasar pertama dalam mengembangkan kemampuan fisik, kognitif, bahasa, sosial emosional, konsep diri, disiplin, kemandirian, seni, moral dan nilai-nilai agama. Upaya pengembangan tersebut dapat dilakukan melalui kegiatan bermain seraya belajar. Alternatif media tersebut diantaranya yaitu Game edukasi pada smartphone atau tablet dengan sistem operasi Android. Game edukasi merupakan bentuk permainan yang dirancang sebagai sarana untuk memberikan suatu pendidikan atau pembelajaran kepada pemainnya. Metode pengembangan aplikasi perangkat lunak yang digunakan pada penelitian ini adalah Rapid Application Development (RAD) yang terdiri dari 4 tahapan yaitu Requirements Planning Phase, User Design Phase, Construction Phase dan Cotuver Phase. Game edukasi ini memiliki 3 menu yaitu belajar, bermain dan info aplikasi, dimana setiap menu memiliki beberapa submenu.
\end{abstract}

Kata Kunci :Game Edukasi, Balita, Rapid Application Development.

\section{PENDAHULUAN}

Game edukasi adalah bentuk permainan yang dirancang untuk memberikan suatu pendidikan atau pembelajaran kepada pemainnya. Game edukasi memiliki potensi yang sangat besar dalam membangun motivasi pada proses pembelajaran (Adi Joko Purnomo, 2017). Game Edukasi digunakan untuk mengajak penggunanya belajar sambil bermain. Melalui proses belajar ini maka penggunanya dapat memperoleh ilmu pengetahuan, sehingga Game edukasi merupakan terobosan baru yang digunakan dalam dunia pendidikan.

Bawah lima tahun atau sering disingkat sebagai Balita merupakan salah satu priode usia manusia setelah bayi dengan rentang usia dimulai dari dua sampai dengan lima tahun. Usia tersebut merupakan masa menerapkan dasar pertama dalam mengembangkan kemampuan fisik, kognitif, bahasa, sosial emosional, konsep diri, disiplin, kemandirian, seni, moral dan nilai-nilai agama. Upaya pengembangan tersebut dapat dilakukan melalui kegiatan bermain seraya belajar.

Berdasarkan uraian tersebut, peneliti tertarik melakukan penelitian dengan judul "Aplikasi Game Edukasi Berbasis Android Sebagai Media Pembelajaran Pada Anak Balita”. Untuk meningkatkan minat belajar anak mengenal namanama buah dan hewan dengan disertai audio berbahasa Indonesia, Inggris dan Arab, sehingga memudahkan anak untuk belajar.

\section{METODE PENELITIAN}

- Metode Pengembangan Perangkat Lunak

Dalam penelitian ini metode pengembangan perangkat lunak yang digunakan adalah Metode Rapid application development (RAD). Adapun tahapantahapannya adalah sebagai berikut :

a) Requirements phase

Proses pengumpulan data dilakukan dengan melakukan observasi, wawancara dan juga studi literatur seperti jurnal, artikel, skripsi, website dan buku yang berhubungan dengan aplikasi game edukasi berbasis android. Dan juga pengumpulan bahan-bahan yang digunakan untuk pembuatan aplikasi game edukasi berbasis android sebagai media pembelajaran anak balita.

b) User Design Phase

Pada tahap perancangan desain aplikasi game edukasi pemodelan yang dipakai yaitu Unified Modeling Language (UML) dengan definisi use case diagram.

c) Construction Phase

Pada tahap pembangunan aplikasi game edukasi yang dibuat menggunakan aplikasi Android Studio sesuai dengan proses perancangan.

d) Cutover Phase

Pada tahapan pengujian aplikasi game edukasi yang telah dibangun, yang mana pada penelitian ini proses pengujian dilakukan menggunakan teknik Black Box. 


\section{HASIL DAN PEMBAHASAN}

Hasil dan pembahasan merupakan implementasi dari penerapan metode Rapid Application Development (RAD) yang digunakan untuk membangun Game Edukasi sebagai media pembelajaran yang menyenangkan untuk anak balita.

a) Requirements Phase

Pada tahap Requirements phase merupakan proses melakukan pengumpulan bahan atau data. Bahan yang diperlukan adalah gambar, text, dan audio, yang penulis dapat dari berbagai sumber dan sebagian penulis buat sendiri menggunakan software CorelDraw dan Adobe Photoshop.

\section{- Background}

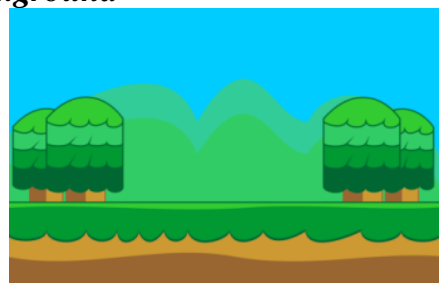

Gambar 1 Background Aplikasi Game Edukasi

- Logo

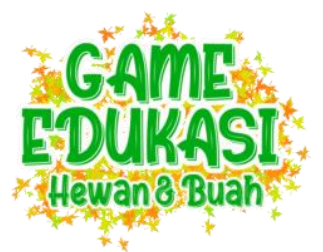

Gambar 2 Logo Game Edukasi hewan dan buah

- Panel dan Ribbon Text
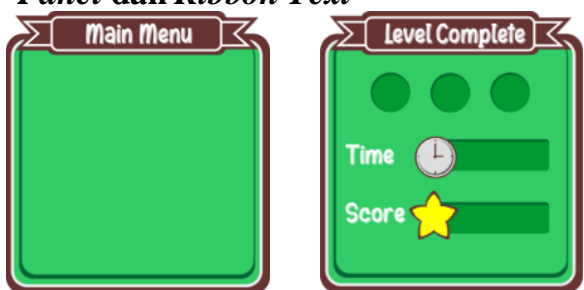

Gambar 3 Panel dan Ribon text

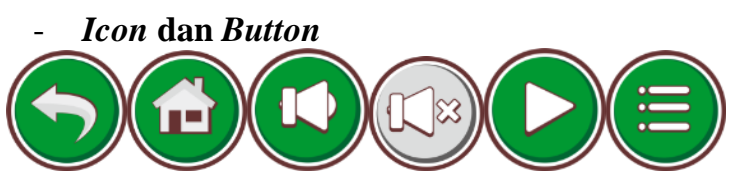

Gambar 4 Icon pada Game Edukasi

\section{Belajar}

\section{Bermain}

\section{Info}

Gambar 5 button pada Game Edukasi
- Hewan dan Buah

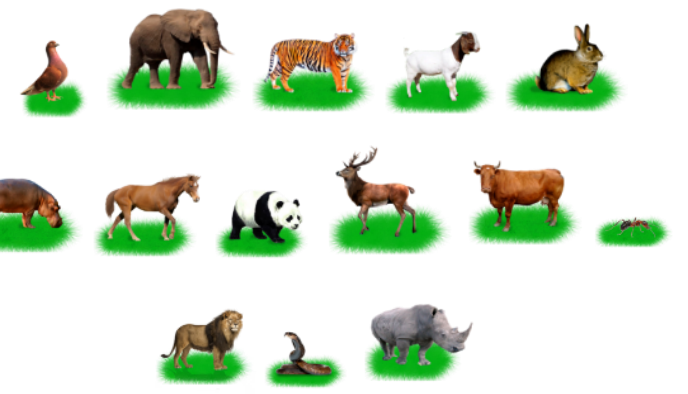

Gambar 6 gambar hewan pada Game Edukasi

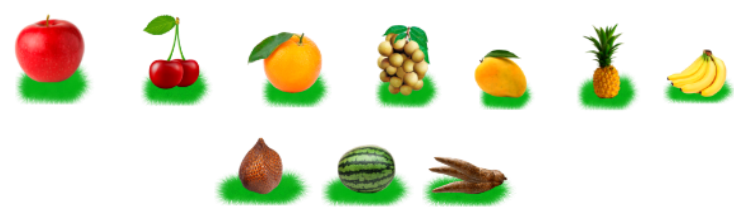

Gambar 7 gambar buah pada Game Edukasi

- Font

Font yang digunakan pada Game Edukasi adalah buble dan grobold.

- Audio

Audio menggunakan format $\mathrm{Mp} 3$, berikut beberapa audio pendukung yang digunakan, seperti :

a. Audio Pengucapan nama hewan dan buah dalam bahasa Indonesia, Inggris dan Arab.

b. Audio Background musik

c. Audio efek Game

b) User Design Phase

\section{- Perancangan Storyboard}

Perancangan storyboard merupakan tahap menggambarkan panduan mengenai segala sesuatu tentang tampilan aplikasi yang akan dibangun pada tahap Contruction Phase. Perancangan storyboard dapat dilihat pada Tabel 1.

Tabel 1 Perancangan Storyboard

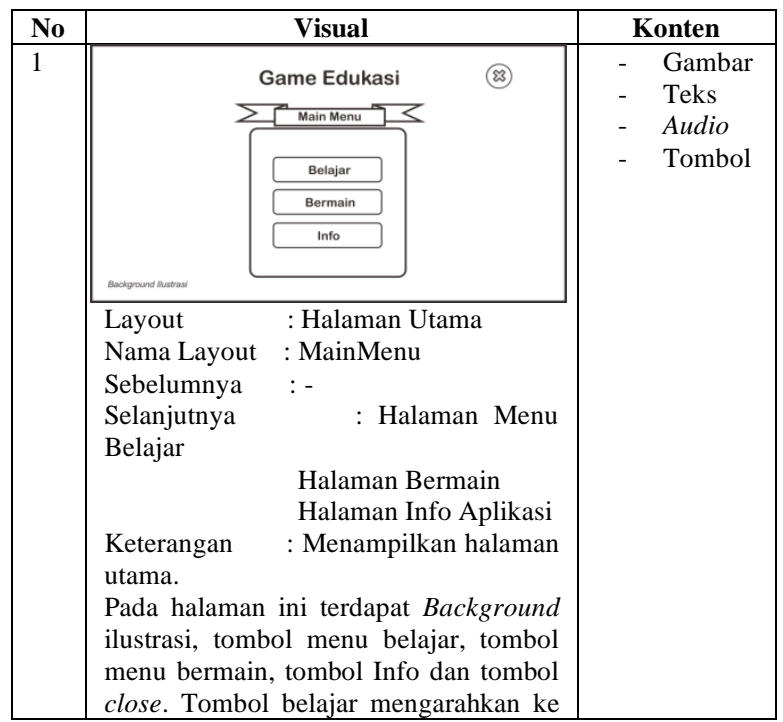




\begin{tabular}{|c|c|c|c|}
\hline No & \multicolumn{2}{|c|}{ Visual } & \multirow[t]{2}{*}{ Konten } \\
\hline & $\begin{array}{l}\text { halaman menu bel } \\
\text { mengarahkan ke } \\
\text { tombol info meng } \\
\text { info aplikasi dan to } \\
\text { untuk menutup apl }\end{array}$ & $\begin{array}{l}\text { tombol bermain } \\
\text { laman bermain, } \\
\text { kan ke halaman } \\
\text { l close berfungsi }\end{array}$ & \\
\hline \multirow[t]{2}{*}{2} & \multicolumn{2}{|c|}{ 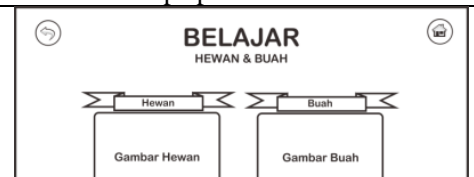 } & \multirow[t]{2}{*}{$\begin{array}{ll}\text { - } & \text { Gambar } \\
\text { - } & \text { Teks } \\
\text { - } & \text { Audio } \\
\text { - } & \text { Tombol }\end{array}$} \\
\hline & \multicolumn{2}{|c|}{$\begin{array}{l}\text { Layout : Halaman Menu Belajar } \\
\text { Nama Layout : MenuBelajar } \\
\begin{array}{l}\text { Sebelumnya : Halaman Utama } \\
\text { Selanjutnya : Halaman Belajar Hewan } \\
\text { Halaman Belajar Buah }\end{array} \\
\text { Keterangan : Menampilkan halaman } \\
\text { Menu Belajar. } \\
\text { Pada halaman ini terdapat Background } \\
\text { ilustrasi, tombol belajar hewan, tombol } \\
\text { belajar buah, tombol kembali dan } \\
\text { tombol home. tombol belajar hewan } \\
\text { mengarahkan ke halaman belajar hewan, } \\
\text { tombol belajar buah mengarahkan ke } \\
\text { halaman belajar buah, tombol kembali } \\
\text { mengarahkan ke halaman sebelumnya } \\
\text { dan tombol home ke halaman utama. }\end{array}$} & \\
\hline \multirow[t]{3}{*}{3} & \multirow{2}{*}{\multicolumn{2}{|c|}{ (5) $\underset{\text { HEWAN \& BUAH }}{\text { BELAJAR }}$}} & \multirow{3}{*}{$\begin{array}{ll}\text { - } & \text { Gambar } \\
\text { - } & \text { Teks } \\
\text { - } & \text { Audio } \\
\text { - } & \text { Tombol }\end{array}$} \\
\hline & & & \\
\hline & \multicolumn{2}{|c|}{$\begin{array}{l}\text { Layout : Halaman Belajar Hewan } \\
\text { Nama Layout : BelajarHewan } \\
\text { Sebelumnya : Halaman Menu Belajar } \\
\text { Selanjutnya : - } \\
\text { Keterangan : Menampilkan halaman } \\
\text { belajar hewan. } \\
\text { Pada halaman ini menampilkan gambar- } \\
\text { gambar hewan dengan tombol nama- } \\
\text { nama hewan dalam bahasa Indonesia, } \\
\text { bahasa Inggris dan bahasa Arab yang } \\
\text { ketika ditekan akan mengeluarkan audio } \\
\text { pengucapannya. tombol kembali } \\
\text { mengarahkan ke halaman sebelumnya } \\
\text { dan tombol home ke halaman utama. }\end{array}$} & \\
\hline \multirow[t]{3}{*}{4} & \multirow{2}{*}{\multicolumn{2}{|c|}{ (9) $\quad$ BELAJAR }} & \multirow{3}{*}{$\begin{array}{ll}\text { - } & \text { Gambar } \\
\text { - } & \text { Teks } \\
\text { - } & \text { Audio } \\
\text { - } & \text { Tombol }\end{array}$} \\
\hline & & & \\
\hline & \multicolumn{2}{|c|}{$\begin{array}{l}\text { Layout } \\
\text { Nama Layout } \\
\text { Sebelumnya }\end{array}$} & \\
\hline
\end{tabular}

\begin{tabular}{|c|c|c|}
\hline No & Visual & Konten \\
\hline & $\begin{array}{l}\text { mengarahkan ke halaman sebelumnya } \\
\text { dan tombol home ke halaman utama. }\end{array}$ & \\
\hline 5 & $\begin{array}{l}\text { MEMORIGAME } \\
\text { Layout : Halaman Bermain } \\
\text { Nama Layout : MemoriGame } \\
\text { Sebelumnya : Halaman Utama } \\
\text { Selanjutnya : Halaman Menu } \\
\text { Bermain } \\
\text { Keterangan : Menampilkan halaman } \\
\text { bermain. } \\
\text { Pada halaman ini terdapat Background } \\
\text { ilustrasi, tombol play, tombol kembali, } \\
\text { tombol pengaturan dan tombol home. } \\
\text { tombol play mengarahkan ke menu } \\
\text { bermain, tombol kembali mengarahkan } \\
\text { ke halaman sebelumnya, tombol } \\
\text { pengaturan mengarahkan ke pengaturan } \\
\text { dan tombol home mengarahkan ke } \\
\text { halaman utama }\end{array}$ & $\begin{array}{ll}\text { - } & \text { Gambar } \\
\text { - } & \text { Teks } \\
\text { - } & \text { Audio } \\
\text { - } & \text { Tombol }\end{array}$ \\
\hline 6 & $\begin{array}{l}\text { : Halaman Menu } \\
\text { Layout } \\
\text { Bermain } \\
\text { Nama Layout : MenuBermain } \\
\text { Sebelumnya : Halaman Bermain } \\
\text { Kelanjutnya : Malaman Level } \\
\text { Keterangan : Menampilkan halaman } \\
\text { menu bermain. } \\
\text { Pada halaman ini terdapat menu bermain } \\
\text { hewan dan buah ketika ditekan akan } \\
\text { mengarahkan ke halaman level. }\end{array}$ & $\begin{array}{ll}\text { - } & \text { Gambar } \\
\text { - } & \text { Teks } \\
\text { - } & \text { Audio } \\
\text { - } & \text { Tombol }\end{array}$ \\
\hline 7 & $\begin{array}{l}\text { Layout } \\
\text { Nama Layout } \quad \text { : Level } \\
\text { Sebelumnya } \\
\text { Bermain } \\
\text { Selanjutnya : Halaman Menu } \\
\text { Keterangan : Menampilkan halaman } \\
\text { level bermain. } \\
\text { Pada halaman ini menampilkan level } \\
\text { permainan dari level mudah sampai level } \\
\text { sulit. }\end{array}$ & $\begin{array}{ll}\text { - } & \text { Gambar } \\
\text { - } & \text { Teks } \\
\text { - } & \text { Audio } \\
\text { - } & \text { Tombol }\end{array}$ \\
\hline 8 & 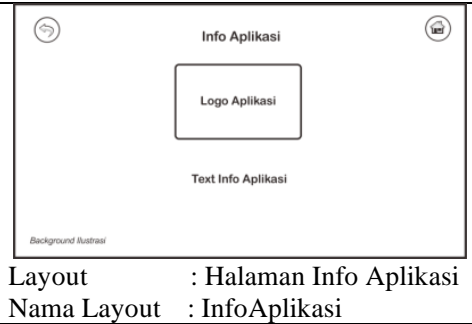 & $\begin{array}{ll}- & \text { Gambar } \\
- & \text { Teks } \\
\text { - } & \text { Audio } \\
\text { - } & \text { Tombol }\end{array}$ \\
\hline
\end{tabular}




\begin{tabular}{|l|l|l|}
\hline No & \multicolumn{1}{|c|}{ Visual } & Konten \\
\hline & Sebelumnya : Halaman Utama & \\
& Selanjutnya : - & \\
Keterangan : Menampilkan halaman & \\
info apliaksi. & $\begin{array}{l}\text { Pada halaman ini menampilkan logo } \\
\text { aplikasi, text tentang aplikasi, terdapat }\end{array}$ & \\
& tombol kembali yang akan mengarah ke & \\
& halaman sebelumnya dan tombol home & \\
yang mengarahkan ke halaman utama. & \\
\hline
\end{tabular}

- Perancangan Menu Navigasi

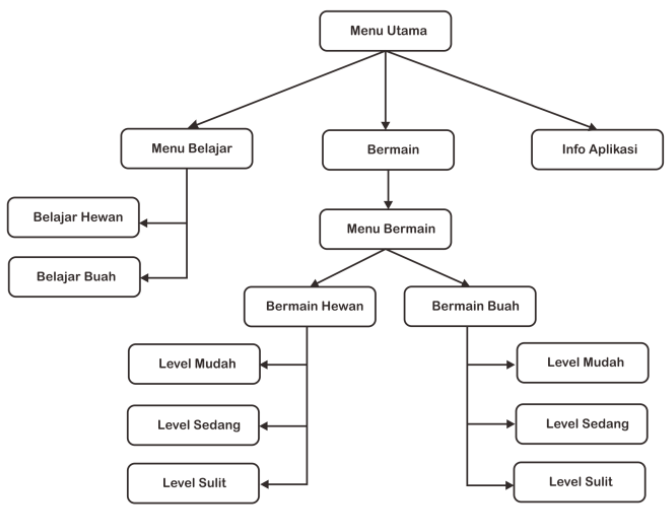

Gambar 8 Rancangan Menu Navigasi

\section{- Usecase Diagram}

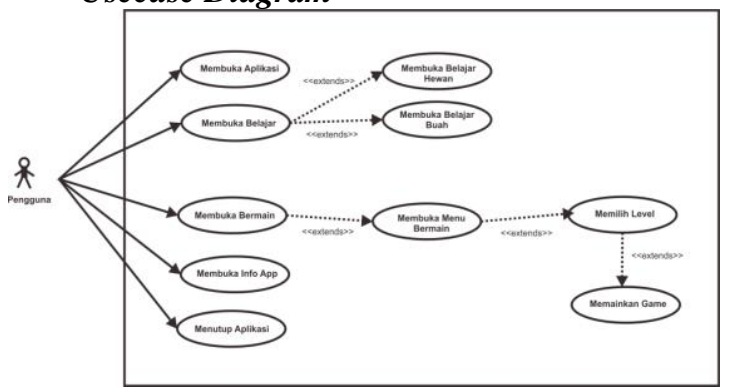

Gambar 9 Usecase Diagram

\section{c) Construction Phase}

Pada tahap ini dilakukan proses pembuatan Game Edukasi hewan dan buah sesuai storyboard yang telah dibuat sebelumnnya. Secara garis besar Game Edukasi hewan dan buah ini terdiri dari pembelajaran mengenal nama hewan dan buah dalam bahasa indonesia, inggris dan arab, serta terdapat memori Game hewan dan buah.

Pembuatan Game Edukasi hewan dan buah ini dimulai dengan mendesain halaman dan semua aset Game di Coreldraw dan Photoshop. Setelah semua desain selesai dibuat dan melakukan pembuatan tampilan Game pada Android Studio, selanjutnya diberikan event agar Game Edukasi berjalan sesuai yang yang diharapkan dan dapat menunjang fungsionalitas serta interaktifitas Game Edukasi hewan dan buah.

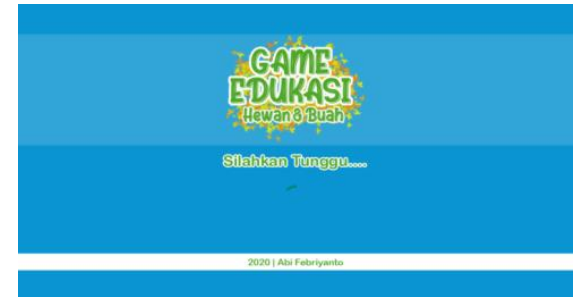

Gambar 10 Tampilan Halaman Splash Screen

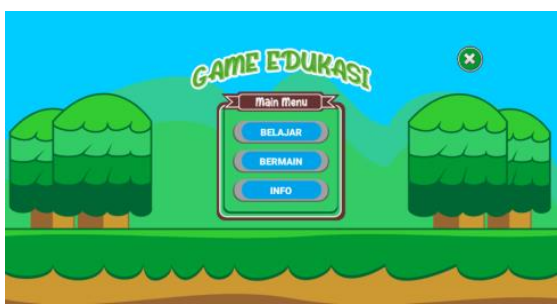

Gambar 11 Tampilan Halaman Utama

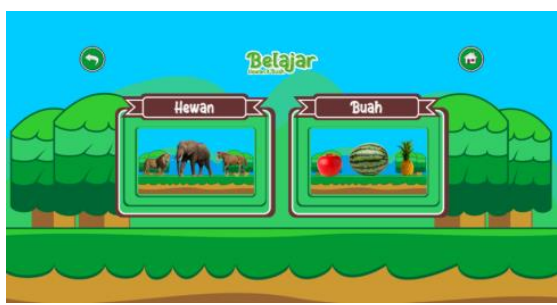

Gambar 12 Tampilan Halaman Menu belajar

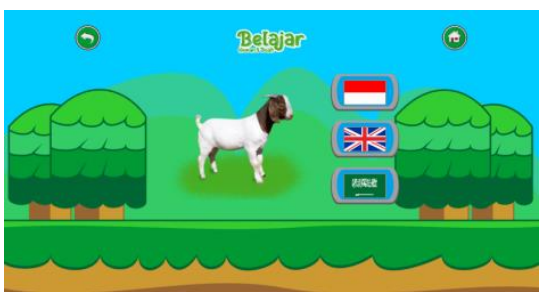

Gambar 13 Tampilan Halaman belajar hewan

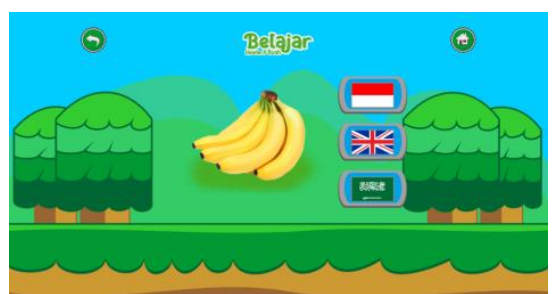

Gambar 14 Tampilan Halaman belajar buah

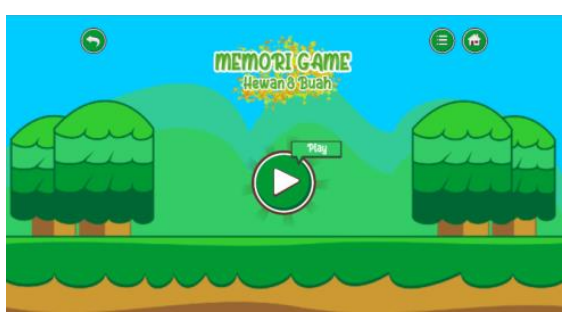

Gambar 15 Tampilan Halaman Bermain 


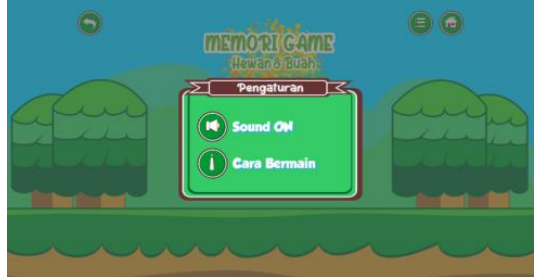

Gambar 16Tampilan Popup setting

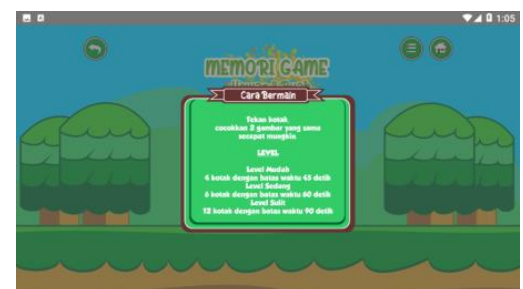

Gambar 17 Tampilan Popup cara bermain

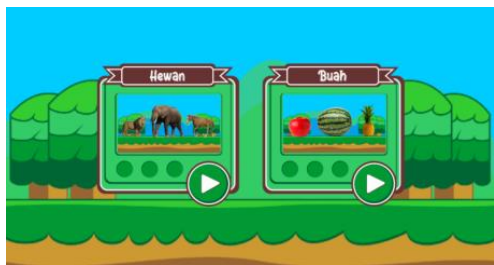

Gambar 18 Tampilan Halaman Menu Bermain

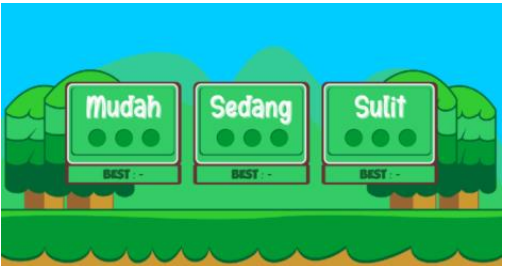

Gambar 19 Tampilan Halaman Level Bermain

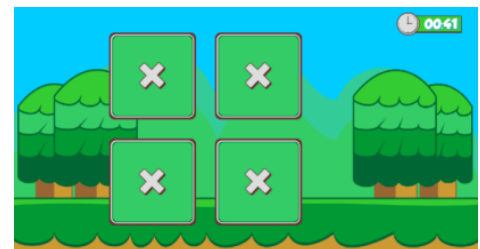

Gambar 20 Tampilan Halaman Level Mudah

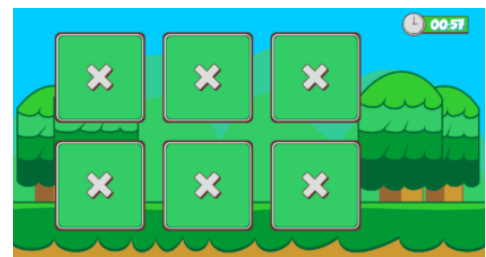

Gambar 21 Tampilan Halaman Level Sedang

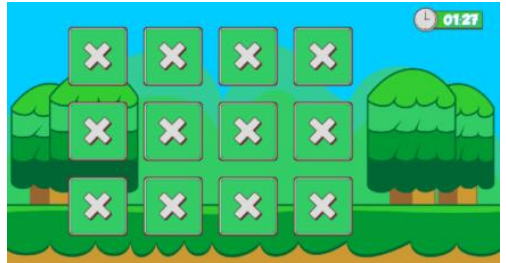

Gambar 22 Tampilan Halaman Level Sulit

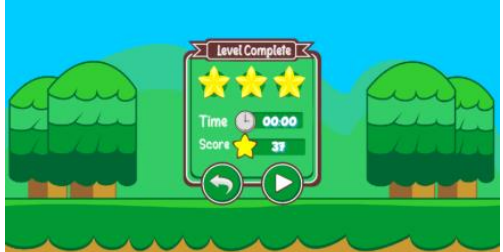

Gambar 23 Tampilan Popup level complete

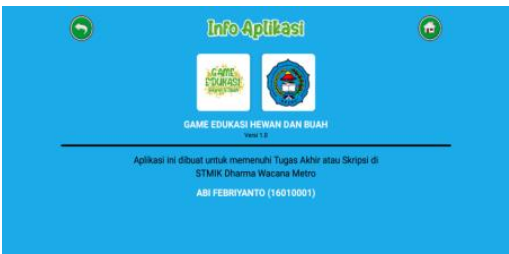

Gambar 24 Tampilan Halaman Info Aplikasi

\section{d) Cutover Phase}

Tahapan Pengujian dilakukan untuk memastikan respons atas suatu event atau masukan akan menjalankan proses yang tepat dan menghasilkan output sesuai dengan rancangan. Pengujian yang dilakukan pada Game Edukasi hewan dan buah menggunakan teknik Black Box.

\section{PENUTUP}

a) Kesimpulan

Berdasarkan hasil pembuatan aplikasi Game Edukasi berbasis android sebagai media pembelajaran untuk anak balita ini, dapat disimpulkan sebagai berikut :

Aplikasi berisi pengenalan nama-nama hewan dan buah yang dilengkapi dengan audio dalam bahasa Indonesia, Inggris dan Arab.

Rancangan terdiri dari Tampilan halaman utama, halaman menu belajar, halaman belajar hewan, halaman belajar buah, halaman bermain, halaman menu bermain, halaman level dan halaman info aplikasi.

Aplikasi Game Edukasi berbasis android bersifat offline yang dibuat menggunakan Android Studio.

\section{b) Saran}

Pada aplikasi Game Edukasi berbasis android sebagai media pembelajaran untuk anak balita ini masih memiliki beberapa kekurangan. Dalam upaya pengembangan aplikasi, berikut beberapa saran yang dapat ditemukan :

Diharapkan pada pengembangan selanjutnya, Aplikasi Game Edukasi ini bersifat online dengan terkoneksi ke database sehingga aplikasi akan lebih ringan dan dapat menampung lebih banyak data hewan dan buah, dan aplikasi bisa diakses di playstore.

Diharapkan pada pengembangan selanjutnya Game Edukasi ini ditambah isi materinya seperti nama-nama transportasi, peralatan sekolah, warna, dan lain-lain. 
DAFTAR PUSTAKA

Muhammad Rahman Koestanto, (2019). "Perancangan Aplikasi Game Psikotes Berbasis Android Menggunakan Metode Rapid Application Development (Rad)".

Ridwan Arif Rahman And Dewi Tresnawati, (2020). "Pengembangan Game Edukasi Pengenalan Nama Hewan Dan Habitatnya Sebagai Media Pembelajaran Berbasis Multimedia," Jurnal Algoritma.

Fahrur Rozi And Khalimatul Khomsatun, (2019). "Rancang Bangun Game Edukasi Pengenalan Warna Untuk Pendidikan Anak Usia Dini Menggunakan Adobe Flash Berbasis Android," Jurnal Ilmiah Penelitian Dan Pembelajaran Informatika.

Dwi Songgo Panggayudi, Wardah Suweleh, And Pramudana Ihsan, (2017). "Media Game Edukasi Berbasis Budaya Untuk Pembelajaran Pengenalan Bilangan Pada Anak Usia Dini," Journal Of Mathematics Education, Science And Technology.

Saptiyanti Sulistioningsih And Fatah Yasin Al Irsyadi, (2018). "Game Edukasi Pengenalan Flora Dan Fauna Berbasis Multimedia Untuk Anak Usia Dini 3-5 Tahun," Jurnal Mitra Pendidikan.

John Roni Coyandra, Irawan, And Juhaini Alie, (2016). "Aplikasi Game Edukasi Pengenalan Bahasa Inggris Berbasis Android Untuk Anak Usia Dini," Jurnal Ilmiah Informatika Global.

Muzliah Rizka Hamadi, Arie S. M. Lumenta, And Muhamad D. Putro, (2017). "Rancangan Bangun Aplikasi Game Edukasi Hafalan Doa Agama Islam," E-Jurnal Teknik Informatika, Vol. Xii.

Adi Joko Purnomo, (2017). "Aplikasi Game Edukasi Untuk Anak Tingkat Sekolah Dasar," Skripsi.

Talizaro Tafonao, (2018). "Peranan Media Pembelajaran Dalam Meningkatkan Minat Belajar Mahasiswa," Jurnal Komunikasi Pendidikan.

Suendri, (2018). "Implementasi Diagram Uml (Unified Modelling Language) Pada Perancangan Sistem Informasi Remunerasi Dosen Dengan Database Oracle," Jurnal Ilmu Komputer Dan Informatika.

A. Prasita Nugroho, Erri Wahyu Puspitarini Dian Wahyu Putra, (2016). "Game Edukasi Berbasis Android Sebagai Media Pembelajaran Untuk Anak Usia Dini," Jurnal Informatika Merdeka Pasuruan.

Suyitno, (2016). "Pengembangan Multimedia Interaktif Pengukuran Teknik Untuk Meningkatkan Hasil Belajar Siswa Smk," Jurnal Pendidikan Teknologi Dan Kejuruan.

Team Dosen, (2017). "Buku Panduan Tugas Akhir STMIK Dharmawacana". 